\title{
Science Education: \\ Defining the Scientifically Literate Person
}

\author{
Poh Tan,
}

Simon Fraser University 


\section{Science Education: Defining the Scientifically Literate Person}

Research on science education is diverse and there are different perspectives on what constitutes an "ideal" science education program. The broadly accepted idea about science education is that it contributed to two main areas of development: social agency and agency in the material world. Social agency provided a sense of respect for knowledge and skills, allowed an individual to do useful work (Anderson, 2007). Agency in the material world contributed to an individual's ability to effectively explain phenomena and influenced both natural and technological systems. Essentially, science has been taught through conceptual change theories, which presented scientific concepts with the intention to change a student's current conceptual framework about a topic and to cultivate and create a critically (scientifically) thinking citizen (Anderson, 2007).

There are two terms to describe a scientifically inclined person: science literate and scientifically literate; and each has its own sets of "criteria". These criteria are segregated into two visions-Visions I and II-which describe the difference between a science literate and a scientifically literate person (Roberts \& Bybee, 2014). Vision I's principles focused on curriculum, knowledge built from pre-existing techniques and methods that are well tested with explanations for the events and objects of the natural world. Vision I came about during the Sputnik era in the late 1950s. Vision II's principles were developed later (based on elements from Vision I) and encouraged an understanding of science through a more holistic lens to consider human endeavour and life situations as part of the solution to creating a scientifically literate person (Roberts \& Bybee, 2014). Specifically, Vision II points to a scientifically literate person as someone who "reflects critically on information and appreciates and understands the impact of science on everyday life" (p. 547). It is important to note that there are multiple interpretations of Vision I and Vision II of the science literate and scientifically literate person depending on the organization, group or individual who defines it. In the context of this paper, I have chosen England's Nuffield Foundation Twenty First Century Science Project's definition of Vision II of a scientifically literate person. Vision I's criteria of a science literate person are a compilation of Douglas Roberts' literature review between 1950 and 2007. (www.nuffieldfoundation.org/twenty-first-centuryscience/gcse-science). Table 1 outlines the criteria for both Vision I and Vision II of a science and scientifically literate person. 
Table 1. Two visions of science education and of the scientifically literate person.

\begin{tabular}{|c|c|}
\hline Vision I & Vision II \\
\hline $\begin{array}{l}\text { A science literate person is one who: } \\
\text { - Is aware that science, math and } \\
\text { technology are interdepended enterprises } \\
\text { with strengths and weaknesses. } \\
\text { - Understands key concepts and } \\
\text { principals in science. } \\
\text { - Is familiar with the natural world } \\
\text { and recognize diversity and unity. } \\
\text { - Uses scientific knowledge and } \\
\text { scientific ways of thinking. }\end{array}$ & $\begin{array}{l}\text { A scientifically literate person is one } \\
\text { who: } \\
\text { - Appreciates and understands the } \\
\text { impact of science and technology on } \\
\text { everyday life. } \\
\text { - Takes informed personal science } \\
\text { decisions about health and energy } \\
\text { resources. } \\
\text { - Reads and understands the essential } \\
\text { points of media reports and about } \\
\text { matters that involve science. } \\
\text { - Reflects critically on information } \\
\text { included in and more importantly } \\
\text { omitted from reports. } \\
\text { - Takes part confidently in discussions } \\
\text { with others about issues involving } \\
\text { science. }\end{array}$ \\
\hline
\end{tabular}

Science literacy and scientific literacy both appeared in literature in the 1950s; however the two terms are not interchangeable despite being used as synonyms for each other in many articles. Science literacy is said to be important to enable one to sift through the massive amount of information and to decipher fact from fiction. In part, the role of science literacy is to encourage critical reading related to one's welfare and democracy (Fischer, 2011). Scientific literacy, on the other hand, is about learning how science fits appropriately with personal and societal perspectives for a complete grasp of issues. It is not surprising that Visions I and II have overlapping elements with each other and both contributed to the definition of scientific thinking. Vision I gives meaning to scientific literacy by outlining the processes and products of science from more technical perspectives. It is important to remember that even though Vision I suggests a more technical standpoint of science literacy (knowledgeability), the process of science learning within Vision I is built on critical skills of questioning, acting and recognizing facts. In addition to these critical skills, Vision II has elements that overlap with Vision I with an added component to include a more holistic ways of thinking of science. Following Nuffield Foundation's definition of a scientifically literate person, Vision II 
brings the critical act of reflectivity where, in addition to learning science from a technical perspective, learners also are introduced to science within a context of one's place and situation. According to Roth and Barton, Vision II is about "[being in] science-related situations in which considerations other than science [i.e. to think about scientific issues associated with individual and social purposes] have an important place at the table" (Roth \& Barton, 2004).

According to Roberts, (2007) each Vision can be viewed as an extreme of the scientific literacy spectrum. Within a classroom, an educator may teach using a science infused curriculum that adopts and integrates elements from each Vision to support the student's learning but not necessarily solely focused on Vision I or II at any time or in any given activity. Table 2 provides examples of the type of elements one may consider when using both Vision I (knowledgeability) and II (reflectivity) as guides for developing science lessons. In the same table, I have attempted to demonstrate how elements from one Vision can build on or inform the other (black arrows). For example, specific questions can be posed to first obtain knowledgeability of science content (arrow 1). After obtaining content, questions can be posed to an appropriate level of understanding that considers other social perspectives (i.e. reflectivity). In another example, reflection from a set of investigations (arrow 2) may contribute to broader inquiries and explanations and further stimulate creativity for new sets of experiments to occur (arrow 3). Similarly for arrow 4, scientific argumentation can both begin and end with factual evidence (knowledgeability) and begin and end with a holistic perspective of the evidence (i.e. considers multiple levels of argumentation and is not limited to only one perspective, for example, only considering statistical evidence). The dynamic relationship between Vision I and II may contribute to building scientific knowledge, promote reflective thinking and support the development of a student's "ability to advance [scientific] understandings (Kuhn, 2010).

Table 2. Examples of how each Vision can inform and build on each other. Black arrows indicate how elements from each Vision can build or inform the other with a symbiotic relationship. 
- Asking questions

$\longrightarrow$ Contextual and situational questioning

- Planning and carrying out investigations

- Analyzing and interpreting data

- Constructing explanation

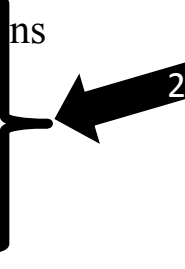

- Reflective on investigations and outcomes

- Expressive creativity for re-testing investigations and explaining unexpected outcomes

- Engaging in argument with factual evidence

- Engaging in argumentation with factual evidence from a holistic perspective

Adapted from Roth, 2014

From my personal experience as an apprentice of science for more than 25 years, my science teachers and professors focused primarily on elements from Vision I (knowledgeability and content). It was not until I began graduate school that I had to independently practice 'reflectivity' for my research. My attempts at 'reflectivity' were immature, uninformed and often masked by intentions to try to find the quickest solutions to an experiment in pursuit of winning the publication and discovery race against my peers. I was not encouraged or supported to reflect on my actions and on my research through a "holistic lens" (Roth \& Barton, 2004) to consider other "social purposes" (Roberts \& Bybee, 2014) that went beyond the laboratory bench. I believe strongly that if I had been given the opportunity to truly reflect on my actions and research as a scientist, I would have considered and tested different approaches for solving problems in the laboratory that may have contributed to the field in a more significant capacity. As Schön, describes in his book Educating the Reflective Practitioner, reflecting 'in-action' is a form of experimentation with "thoughtful inventions of [new experiments] based on appreciation of the results from earlier moves" (Schön, 1987, p. 158) to find the best and most appropriate solution to problems not encountered previously (i.e. new problems or previous problems where existing knowledge and solutions are no longer adequate). Integrating knowledgeability and reflectivity helps to develop the foundations of content based on scientific process and contribute to scientific understanding.

Both Visions of science literacy are well understood amongst science education scholars in the field. Dr. John Murray suggests that Canadian science education has been greatly influenced by an "American experience". In particular, the curricular frameworks that are present in Canadian public school today arise from American science policy, theory, assumptions and goals of science education. He acknowledges that in a Canadian context there are many viewpoints on science literacy and that prior to tackling the issue of "defining" science literacy the public's perception of Canadian science education must be addressed. He identified five major issues in his report and one of which is the "failure of Canadians to recognize that science and technology are integral parts of our society's culture" (Murray, 2016). Furthermore, Marcel Risi echoes his concern when he 
spoke to the "inadequacy of teaching science as only a body of discipline-based knowledge instead of through a trans-disciplinary matrix; as an ecology of the crossroads" (Risi, 1982). In addition to his discussion of science literacy, Roberts further proposes that the "two senses [referring to the Visions I and II] of science literacy have become an aging slogan" (Murray, 2016).

As we move into a new era in science education, perhaps it is "time to talk about science literacy from a new [and alternative] perspective [Vision III] that integrates multiple perspectives about scientific worldview[s]; a system that embeds indigenous systems of knowing and non-Western paradigms" (Murray, 2016). Robin Kimmerer elegantly explains and integrates Western scientific theories and practices with indigenous understandings of the scientific world by drawing on her Potawatomi heritage and her experience as a scientist. In her book, Braiding Sweetgrass: Indigenous Wisdom, Scientific Knowledge, and the Teaching of Plants, Kimmerer (2013), uses narrative approaches to explain intricate relationships between scientists and the non-human world to form a bridge of understanding between Western and indigenous scientific paradigms. Similar to Visions I and II, Vision III is not mutually exclusive from Visions I and II, and instead is part of the scientific literacy continuum.

Murray's alternative vision of scientific literacy has been expanded to include an individuals "abilities, skills, dispositions, and knowledge to engage in Science, Technology, Society and Environment (STSE) issues and debates" (Yore, 2012). Yore's work was later supported by Lin (2014), who explored critical thinking skills with science and non-science undergraduates. She found that Yore's interpretation of Vision III characterized a scientifically literate person as one who 1) understands core ideas through scientific inquiry, 2) have fundamental scientific principles rooted by critical thinking skills and 3) participates from a scientific perspective in socioscientific issues.

Although, at the current moment, there is no "gold standard" definition or assessment to measure if a person is scientifically literate, there are programs, workshops, and assignments, which intend to emulate scientific literacy (or its essence) in the classroom give example if possible. It is generally agreed that the intentions of scientific literacy is to develop students who are persistant and unintimidated in challenging the adequancy of scientific explanations both inside and outside the classroom. Ideally, these students tend to question (instead of blindly accepting) new ideas and concepts presented in popular media and social media to make informed and sound decisions with the highest level of scientific literacy to "create a better and sustainable world for people to live in" (Eshach, 2006). 


\section{References}

Anderson, C. (2007). Perspectives in science learning. In S. K. Abell, \& N. G. Lederman, Handbook of Research on Science Education (pp. 3-30). New York: Routledge.

Bjorklund, D. F. (1995). Children's thinking: developmental function and individiual differences. Pacific Grove, CA, USA: Brooks/Cole Publishing Company.

Eshach, H. (2006). Science literacy in primary schools and pre-schools. Dordrecht, The Netherlands: Springer.

Fischer, C. N. (2011). Changing the science education paradigm: From teaching facts to engaging the intellect: Science education colloquia series. The Yale Journal of Biology and Medicine, 247-251.

Kimmerer, R. W. (2013). Braiding sweetgrass: Indigeneous wisdom, scientific knowledge, and the teaching of plants. Minneapolis: Milkweed Editions.

Kuhn, D. (2010). What is scientific thinking and how does it develop? In U. Goswami, Handbook of Childhood Cognitive Development, 2nd Edition (pp. 497-523). West Sussex, UK: Wiley-Blackwell.

Lin, S. S. (2014). Science and non-science undergraduate students' critical thinking and argumentation performance in reading a science news report. International Journal of Science and Mathematics Education, 1023-1046.

Murray, J. (2016). Science education in Canada to 2030. Brandon, Manitoba: John Murray, Faculty of Education, Brandon University, Manitoba.

Murray, J. (2016, June 1). Science Education in Canada to 2030. (P. Tan, Interviewer)

Risi, M. (1982). Macroscole: A holistic appraoach to science teaching. A discussion paper. . Ottawa, Ontario: Publications Office, Science Council of Canada. .

Roberts, D. A. (2007). Scientific Literacy/Science Literacy. In S. K. Abell, \& N. G. Lederman, Handbook of Research on Science Education (pp. 729-781). New York, NY: Routledge.

Roberts, D., \& Bybee, R. (2014). Scientific Literacy, Science Literacy and Science Education. In N. G. Lederman, \& S. K. Abell, Handbook of Research on Science Education (pp. 545-558). New York: Routledge.

Roth, W., \& Barton, A. (2004). Rethinking scientific literacy. New York, NY: Routledge Falmer. 
Schön, D. (1987). Educating the reflective practitioner. New Jersey, USA: John Wiley and Sons.

Yore, L. D. (2012). Science literacy for all - More than a slogan, logo or rally flag! In K. C. Tan, \& M. Kim, Issues and challenges in science education research: Moving forward (pp. 5-23). Dordrecht, The Netherlands: Springer. 